\title{
O COTIDIANO FANTÁSTICO NA PROPAGANDA DE HAVAIANAS: O COMERCIAL TELEVISIVO COMO TECNOLOGIA DO IMAGINÁRIO
}

\author{
The fantastic quotidian in Havaianas's advertisement: The television commercial \\ as a technology of the imaginary
}

\section{El cotidiano fantástico en la propaganda de Havaianas: El comercial televisivo como tecnología de lo imaginario}

\author{
Juliana Tonin ${ }^{1}$ \\ Larissa Azubel ${ }^{2}$ \\ Gabriela Kurtz ${ }^{3}$ \\ Karina Pereira Weber ${ }^{4}$
}

\section{Resumo}

A partir desse estudo buscamos pensar o papel do comercial televisivo como uma tecnologia do imaginário contemporâneo, em sua estimulação para o conhecimento de novas referências, potencializando novas representações. Assim, selecionamos para análise duas propagandas de uma marca reconhecida por sua brasilidade, as sandálias Havaianas. A perspectiva adotada é a da sociologia compreensiva e autores como Durand, Maffesoli, Lipovetsky e Silva constituem o referencial dessa pesquisa.

Palavras-chave: tecnologias do imaginário, cotidiano, contemporaneidade, Havaianas.

\begin{abstract}
From this study, we seek to think the role of the television commercial as a contemporary technology of the imaginary, in its stimulation of the knowledge of new references, potentiating new representations. Thus, we selected for the analysis two advertisements of a brand recognized by its Brazilianess, the Havaianas sandals. The
\end{abstract}

\footnotetext{
${ }^{1}$ Professora Adjunta do Programa de pós-graduação em Comunicação Social da PUCRS. E-mail: juliana.tonin@pucrs.br

${ }^{2}$ Doutoranda do Programa de Pós-Graduação em Comunicação Social da PUCRS - Brasil. Bolsista CNPq. E-mail: larissalauffer@gmail.com

3 Mestranda do Programa de Pós-Graduação em Comunicação Social da PUCRS. E-mail: gabriela@sidicom.com.br

${ }^{4}$ Mestranda do Programa de Pós-Graduação em Comunicação Social da PUCRS. E-mail: karinaweber.rs@gmail.com
} 
O cotidiano fantástico na propaganda de havaianas: O comercial televisivo como tecnologia do imaginário

de Gabriela Kurtz, Juliana Tonin, Karina Pereira Weber e Larissa Azubel

perspective adopted is the comprehensive sociology, and authors as Durand, Maffesoli, Lipovetsky and Silva constitute this research referential.

Keywords: technologies of the imaginary, quotidian, contemporaneity, Havaianas.

\section{Resumen}

A partir de este estudio logramos pensar el papel del comercial televisivo como una tecnología de lo imaginario contemporáneo, en su estimulación para el conocimiento de nuevas referencias, potencializando nuevas representaciones. De este modo, selecionamos para nuestra analise dos propagandas de una marca reconocida por su brasilidad, las sandalias Havaianas. La perspectiva adotada es la de la Sociología Comprensiva y los autores como Durand, Maffesoli, Lipovetsky y Silva constituyen el referencial de esta investigación.

Palabras-clave: tecnologías de lo imaginario, cotidiano, contemporaneidad, Havaianas.

O objetivo do presente artigo é refletir sobre o papel dos comerciais televisivos como tecnologias do imaginário contemporâneo, em sua estimulação para o conhecimento de novas referências, potencializando novas representações. Para pensarmos esta questão, na publicidade, selecionamos para análise o caso de duas propagandas da marca Havaianas, a serem detalhadas mais adiante. Quanto à teoria envolvida neste processo, começaremos por esboçar uma noção central, a de imaginário, de acordo com os autores Gilbert Durand, Michel Maffesoli e Juremir Machado da Silva.

Para Durand (1998: 10), o imaginário pode ser compreendido como uma espécie de museu que abarca "todas as imagens passadas, possíveis, produzidas e a serem produzidas". Segundo ele, o imaginário é como "uma re-presentação incontornável, a faculdade da simbolização de onde todos os medos, todas as esperanças e seus frutos culturais jorram continuamente" (1998: 117). De acordo com o autor, temos, ainda, concomitantemente, no social, um imaginário atualizado e um imaginário potencializado. E essa noção constitui-se, como um campo de estudo fundamental para a sociologia; pois, o sagrado, o mito, o lúdico, os sonhos e o fantástico, são objetos que merecem a atenção dos pesquisadores. 
Não só a função fantástica participa na elaboração da consciência teórica, como também [...], não desempenha na prática o simples papel de refúgio afetivo, ela é bem uma auxiliar na ação. [...] Ora toda a cultura inculcada pela educação é um conjunto de estruturas fantásticas. [...] A prática de início é ensinada de maneira teorética extrema: sob a forma de apólogos, fábulas, exemplos, lugares seletos nas literaturas, no museu, na arqueologia ou na vida dos homens ilustres. E os jogos não passam de um primeiro ensaio dos mitos, lendas e contos. [...] Neste "mundo pleno" que é o mundo criado pelo homem, o útil e o imaginativo estão inextricavelmente misturados. [...] a alvorada de toda a criação do espírito humano, teórica ou prática, é governada pela função fantástica. [...] ela está na raiz de todos os processos da consciência, revela-se como a marca originária do Espírito (DURAND, 2002: 397).

Essa breve incursão pela noção de imaginário de Durand traz à tona a pertinência da relação que a publicidade pode ter como "praticante do imaginário". Ela, através da elaboração de anúncios voltados para o lúdico, o onírico, o fantástico, para além da apresentação meramente informativa sobre as características dos produtos, acaba se alimentado da atmosfera imaginária de cada época e, através de um apelo sedutor, cria novas histórias, formas de ver, de se ver, de sentir e de pensar o mundo. E tudo isso é potencialmente estimulante para a visualização e surgimento de novas representações. Por esta razão, consideramos a publicidade uma tecnologia do imaginário, conforme define Silva:

As tecnologias do imaginário são dispositivos (Foucault) de intervenção, formatação, interferência e construção das "bacias semânticas" que determinarão a complexidade (Morin) dos "trajetos antropológicos" de indivíduos ou grupos. Assim, as tecnologias do imaginário estabelecem "laço social" (Maffesoli) e impõem-se como o principal mecanismo de produção simbólica da "sociedade do espetáculo" (Debord) (sic)" (SILVA, 2012: 20-1).

Segundo Silva, vivemos no imaginário, que dá significado e impulso às nossas práticas, sendo suas tecnologias, motores e reservatórios afetivos, imagéticos e simbólicos. Assim, as tecnologias do imaginário "transformam o ar do tempo em corrente de uma época, dando consistência ao etéreo" (SILVA, 2012: 43).

Ainda segundo o autor, o imaginário se materializa por meio dessas tecnologias que lhe são próprias, posto que são seus instrumentos de propagação, disseminação e cristalização. "As tecnologias do imaginário ora se apresentam como meios (rádio, televisão), ora como procedimentos, técnicas ou disciplinas (publicidade) ou, finalmente, como formas de expressão (literatura)", de forma que, "paradoxal, a publicidade, principal tecnologia contemporânea do imaginário, seduz para persuadir, brinca para convencer, entra no jogo do receptor para tentar neutralizá-lo" (SILVA, 2012: 69). 
O cotidiano fantástico na propaganda de havaianas: O comercial televisivo como tecnologia do imaginário

de Gabriela Kurtz, Juliana Tonin, Karina Pereira Weber e Larissa Azubel

No entanto, é preciso salientar que compreender o imaginário e poder elaborar uma leitura de suas manifestações é sempre uma tentativa de aproximação, pois, como revela Durand, ele é ambivalente e alógico, tornando-se necessário atentar às metáforas que ele apresenta. Em sua formação, sobrepõem-se diversas esferas, tornando sua manifestação interligada com o ambiente geográfico (clima, latitude, localizações continentais, oceânicas, montanhosas, etc.), o lúdico (jogos), a aprendizagem e os símbolos e convenções, instituídos pela sociedade, para que aconteça uma relação adequada dos membros entre si (DURAND, 1998: 91).

Por sua vez, para Maffesoli, o imaginário pode ser compreendido como alavanca metodológica: captamos o real a partir do que é aparentemente seu contrário, o irreal (ou a ficção ou o fantástico inserido no cotidiano), pois o imaginário é considerado pelo autor, bem como por Patrick Tacussel, como uma atmosfera mental compartilhada (MAFFESOLI, 2012: 107). Fica, portanto, latente a pergunta, como podemos ver o imaginário? De que forma tocar, ler esse irreal que perpassa nosso dia-a-dia?

Maffesoli fornece pistas para essa leitura. Ele acredita que o imaginário e o cotidiano estão intrinsecamente ligados no espírito da contemporaneidade. Segundo o autor (2012), podemos falar nesses dois termos como caracteres essenciais pelos quais nossa sociedade pode ser reconhecível entre os diferentes momentos da história. O cotidiano,

(...) podemos compreendê-lo como o substrato, o solo sobre o qual cresce uma maneira de estar junto, que é a sociedade. Quanto ao imaginário, ele poderia ser esse céu das ideias que, de uma forma um pouco misteriosa, garante a coesão do conjunto social (MAFFESOLI, 2012: 106-107).

O autor compreende (2010) que essa ambiência que é o imaginário se inscreve na vida corrente, no ordinário, banal ou comum, nos microacontecimentos ou em nossos rituais do dia-a-dia. O cotidiano diz respeito ao resíduo, ao que fica nos interstícios da vida oficial.

Assim, nos colocamos diante de outra questão. Que tempo é este narrado, materializado pelas tecnologias de que estamos falando? O termo "contemporâneo" dá vazão a diversas interpretações. A fim de pensá-lo de maneira complexa, pretendemos relacionar, neste momento, os termos pós-modernidade, na perspectiva de Lyotard, e, hipermodernidade, segundo Lipovetsky, na tentativa de entender a conjuntura social em que são veiculados os comerciais de Havaianas. 
O cotidiano fantástico na propaganda de havaianas: O comercial televisivo como tecnologia do imaginário

de Gabriela Kurtz, Juliana Tonin, Karina Pereira Weber e Larissa Azubel

Segundo Lyotard (2011), a condição pós-moderna nos coloca diante da crise da verdade, nas grandes narrativas, em todos os campos do saber do tradicional. Para o autor, o que ocorre é um descrédito de conceitos "caros ao pensamento moderno, tais como 'razão', 'sujeito', 'totalidade', 'verdade', 'progresso'" (LYOTARD, 2011: VIII). Estamos em desordem, nessa temporalidade, que designa "o estado da cultura após as transformações que afetaram as regras dos jogos da ciência, da literatura e das artes, a partir do final do século XIX" (LYOTARD, 2011: XV), e que muda o estatuto do saber quando as sociedades entram na era pós-industrial, "desde, pelo menos, o final dos anos 50" (LYOTARD, 2011: 3).

Sendo assim, a condição pós-moderna desloca os polos de atração: Estadosnações, partidos, profissionais, instituições e tradições históricas não atraem mais e não parecem dever ser substituídos, "pois não se trata verdadeiramente de uma finalidade da vida. Esta é deixada à diligência de cada cidadão. Cada qual é entregue a si mesmo", de forma que, "vemos a passagem das coletividades sociais ao estado de uma massa composta de átomos individuais", mas que não estão isolados, porém tomados em uma textura novel e complexa de relações, "colocados sobre os nós dos circuitos de comunicação". Ainda assim, o indivíduo não estaria, de modo algum, privado de poder sobre as mensagens que o atravessam (LYOTARD, 2011). Contudo, no contexto Lyotardiano, as tecnologias do imaginário de Silva, não são da ordem do controle ou da persuasão, mas da sedução.

Para Lipovetsky (2004), a primazia do presente se instalou menos pela ausência (de sentido, de valor, de projeto histórico) que pelo excesso (de bens, de imagens, de solicitações hedonistas). $\mathrm{O}$ autor entende que a moda foi o principal fator de mudança deste estado pós-moderno para o hipermoderno, uma vez que ela permitiu o desenvolvimento intenso da subjetividade e da individualidade. Assim, o avanço da pósmodernidade para a hipermodernidade se dá pelo fato de que o individualismo, influenciado pelo neoliberalismo, toma conta da corrente que move nossa sociedade.

Reconhecendo, tal como Lyotard, a crise da verdade, a perda do controle institucional e, ressaltando a responsabilidade individual sobre as posturas éticas, autojulgamento e autocrítica, Lipovetsky explica que o consumo acaba servindo como uma fuga:

Na verdade, o que nutre a escala consumista é indubitavelmente tanto a angústia existencial quanto o prazer associado às mudanças, o desejo de intensificar $e$ 
reintensificar o cotidiano. Talvez esteja aí o desejo fundamental do consumidor hipermoderno: renovar sua vivência do tempo, revivificá-la por meio das novidades que se oferecem como simulacros de aventura. É preciso ver o hiperconsumo como uma cura de rejuvenescimento que se reinicia eternamente. [...] Nossa pulsão neofílica é, em primeiro lugar, um exorcismo do envelhecimento do viver subjetivo: o indivíduo desinstitucionalizado, volátil, hiperconsumista, é aquele que sonha assemelhar-se a uma fênix emocional (LIPOVETSKY, 2004: 79-80).

Lipovetsky mostrou que todos os âmbitos da vida se tornaram mercadorias, desde o ensino, a cultura, as relações, o lazer... Neste sentido, o consumo se tornou extremo, hiperconsumo como chamou. Com a subjetividade, o individualismo e o hiperconsumo aflorados, o cotidiano se torna alvo de espetacularizações. A vida nunca foi tão fantástica, já que por todos os lados há um interesse, uma exploração para tornála um especial e diferenciada. Os indivíduos buscam cada vez mais o exclusivo, o diferente na tentativa de tornar cada detalhe único e/ou mais confortável. Deste modo, a vida cotidiana ganha atenção nas suas mais banais situações, o que podemos bem ilustrar através dos comerciais analisados neste artigo.

Em consonância com o pensamento de Lipovetsky, Marcel Mauss (1988) expôs que a vida em sociedade, a realidade, não é o suficiente. É preciso de algo mais, de uma magia que transcenda e ao mesmo tempo extrapole. Este é o lugar no qual se abrem novas possibilidades de referências e que, através das tecnologias do imaginário, dissemina-se no nosso dia-a-dia, possibilitando a manifestação de novas representações.

\section{A MARCA COMO REPRESENTAÇÃO DO IMAGINÁRIO NO COTIDIANO}

A publicidade constantemente se preocupa em aliar os símbolos do cotidiano a situações incomuns, muitas vezes associadas à atmosfera de sonho, irrealidade, fantástica. O ex-CEO da Ferrari North America, Luigi Longinotti-Buitoni (2000), cunhou o termo "dreamarketing" para definir a estratégia de "vender sonhos" para os clientes. Para ele, os sonhos são compostos de símbolos e, todo o consumo possui uma carga simbólica.

[...] chamamos de consumo simbólico os impulsos multissensoriais que ligam emocionalmente a fantasia do cliente ao produto físico. Do ponto de vista do consumo simbólico, os produtos são vistos menos como entidades objetivas e muito mais como símbolos subjetivos. [...] Os produtos e serviços de que os sonhos são feitos contêm naturalmente muito mais peso simbólico do que aqueles que satisfazem necessidades (LONGINOTTI-BUITONI, 2000: 67). 
O cotidiano fantástico na propaganda de havaianas: O comercial televisivo como tecnologia do imaginário

O "dreamarketing" descrito por Longinotti-Buitoni baseia-se na interpretação aliada aos desejos mais fortes dos consumidores. Para ele, as empresas que objetivam se destacar, precisam cativar os clientes pela imaginação, criando experiências fantásticas. Conforme Everaldo Rocha (2006), os publicitários criam uma "sociedade do sonho", revestindo o cotidiano com situações inéditas, inusitadas, que incitam os consumidores a verem o mundo de forma diferente.

É importante perceber que o simbólico existe fortemente na publicidade, e que é articulado de forma consciente, já que a motivação primal na escolha de produtos ou serviços se encontra nos processos sociais e subjetivos (BARBOSA, 2004). Além disso, há outras motivações para o consumo que dependem de aspectos tanto individuais quanto coletivos. Para Brée (2004), este ato de consumo e decisão de compra é definido individualmente por desejos e motivações, atitudes, estilo de vida e personalidade. Já no campo coletivo, é condicionado por aspectos como identificação e pertencimento a grupos.

Além disso, é crucial que exista o entendimento das "regras do jogo" na publicidade. Cada receptor possui competências, que possibilitam que ele "leia" o que lhe é anunciado. É um movimento de retroatividade, onde é preciso que o consumidor conheça as regras, desenvolva suas táticas e haja a negociação por parte do emissor. Sem isso, não é possível estabelecer o canal de comunicação (PIEDRAS, 2008). Em um mundo onde, cada vez mais, o consumidor se torna experiente quanto às regras do jogo e aceita jogar (SILVA, 2012), a publicidade precisa usufruir de mecanismos simbólicos que sejam, ao mesmo tempo, existentes no cotidiano do seu público-alvo e fascinantes, pertencentes ao mundo do sonho e do fantástico. Ela faz isso criando narrativas com fortes cargas simbólicas.

Marcas que se tornam memoráveis entre os consumidores utilizam esta estratégia, a narrativa que articula o simbólico, por diversos motivos. Um deles é o consumismo. Vivemos nesta cultura, onde os produtos são muitos e, segundo Silva (2012), não são vistos cegamente pelo consumidor. Por isso, Laurence Vincent (2005) destaca que manipular as pessoas não é uma estratégia válida, pois “os consumidores anseiam por marcas que representem efetivamente algo, marcas que ajudem a proporcionar significado e ordem em suas vidas" (VINCENT, 2005:12). 
O cotidiano fantástico na propaganda de havaianas: O comercial televisivo como tecnologia do imaginário

de Gabriela Kurtz, Juliana Tonin, Karina Pereira Weber e Larissa Azubel

Ainda conforme o autor, as pessoas estão expostas a um número cada vez maior de mídias diferentes. Contudo, esse não é o maior desafio para as empresas. Estas tantas formas de comunicar uma mensagem propiciam um volume de informação sem precedentes e o alcance e a rapidez da propaganda nunca antes tiveram tamanhas proporções. Assim, "durante os últimos 25 anos, o mundo da propaganda evoluiu para uma indústria sofisticada" (VINCENT, 2005: 13). A técnica devia se aliar a narrativa. Essa, por sua vez, precisava ser contada com muito mais rapidez e apelo visual do que no passado. Assim, a estratégia embasa-se no pressuposto de que as pessoas possuem uma inclinação a serem seduzidas mais facilmente quando há uma história envolvida. Para distinguir a marca comum da marca legendária, Vincent conceitua:

Existe uma distinção básica entre as Marcas Legendárias e todas as demais marcas de produtos. A mitologia da marca usa a narrativa para transmitir uma visão de mundo, um conjunto de crenças sagradas que transcendem os atributos funcionais e cognitivos do produto. A narrativa, que une o consumidor e a marca em um tipo de vínculo existencial, constitui o fundamento da força da marca. A mitologia da marca opera em um ciclo autogratificante que envolve a participação do consumidor (VINCENT, 2005: 19).

É possível estabelecer uma relação entre Vincent e Maffesoli, quando o primeiro afirma que as marcas legendárias normalmente "ganham força pela formação de tribos que compartilham uma aceitação pelas crenças sagradas da marca" (VINCENT, 2005: 34). Quando a narrativa de uma marca já consolidada, com seu sistema de crenças imbuído no consumidor, alia os símbolos do cotidiano com um toque de inusitado, isto propicia novas ligações entre o público-alvo e a marca, tornando-a memorável. Esse é o caso da marca Havaianas, que transformou, por meio de estratégias publicitárias que contemplam os moldes dissertados aqui, chinelos de borracha em sandálias que são sonho de consumo.

\section{ANÁliSE DOS COMERCIAIS "BOLOTA” E “AVÓ”, DA MARCA HAVAIANAS}

Antes de partir para a análise dos comerciais, é importante que abordemos a trajetória da marca Havaianas, bem como seu posicionamento no mercado. Utilizaremos como referência o site oficial das Havaianas (História, [201-]). A história inicia em 1962. O produto foi concebido com inspiração em uma sandália tradicional japonesa, 
O cotidiano fantástico na propaganda de havaianas: O comercial televisivo como tecnologia do imaginário

de Gabriela Kurtz, Juliana Tonin, Karina Pereira Weber e Larissa Azubel

chamada Zori, que substituiu as tiras de tecido e a sola de palha de arroz, que constituíam a original, pela borracha. Na busca pela diferenciação no mercado, em 1970, foi lançado o slogan: "Havaianas. As legítimas.”, focando também na qualidade do produto, as sandálias ainda eram associadas à frase: "Não deformam, não soltam as tiras e não tem cheiro". Nessa época, os comerciais eram protagonizados pelo ator Chico Anysio.

Na década de 1980, as Havaianas atingiram sucesso absoluto entre os brasileiros, chegando a vendar 80 milhões de pares por ano. Contudo, a maior transformação ocorreu na década de 1990. Com o slogan "Todo mundo usa", as Havaianas apostaram na endossagem pesada de sua linha de produtos, cada vez mais diversificada. De acordo com Shimp (2002), a endossagem ocorre quando um produto é anunciado por uma personalidade já conhecida pelo público em áreas diferentes daquela que o produto endossado faz parte. Para o autor, esse recurso é utilizado porque muitas pessoas se identificam com esses personagens e as veem como um modelo para suas aspirações. Malu Mader, Bebeto, Luana Piovani e Hortência eram as personalidades famosas da televisão e do mundo dos esportes que estampavam os comerciais.

O início da internacionalização das Havaianas se deu com a copa do mundo de futebol, de 1998. O lançamento do modelo com uma bandeira do Brasil, na tira da sandália, chamou a atenção de consumidores do mundo todo. Atualmente, as Havaianas são vendidas em mais de 60 países. Almejando o mercado internacional, a marca presenteou os participantes do Oscar, em 2003, com pares exclusivos, o que contribuiu também para que fosse agregado mais valor às sandálias. Em estratégia semelhante, as Havaianas produziram, em parceria com a joalheria H.Stern, sandálias com acabamento em ouro $18 \mathrm{~K}$ e diamantes. Logo, o foco mostrava-se claro: a elitização da marca e diferenciação das concorrentes.

Nos anos que se seguiram, as Havaianas aumentaram a presença no mercado internacional, lançaram novas linhas de sandálias (como a Slim, voltada especificamente ao mercado feminino) e focaram sua estratégia de comunicação na endossagem. O que era chinelo de borracha em 1962, passou a ser sandália, com a agregação de uma série de valores à marca. Um calçado que poderia ser utilizado em qualquer ocasião, e, não apenas associado às praias; com um design inconfundível e garantia de qualidade. Além disso, as Havaianas são um produto constantemente associado à brasilidade, mesmo sendo comercializadas internacionalmente. 
O cotidiano fantástico na propaganda de havaianas: O comercial televisivo como tecnologia do imaginário

de Gabriela Kurtz, Juliana Tonin, Karina Pereira Weber e Larissa Azubel

Após uma breve contextualização, percebemos a relevância das Havaianas. Com a utilização principalmente de comerciais em TV aberta, a marca é capaz de atingir um grande número de pessoas, sendo esta a estratégia principal adotada. Em função disso, optamos por analisar dois comerciais emblemáticos da marca, nos últimos anos. Estes demonstram e sintetizam a estratégia das Havaianas e manifestam situações cotidianas inusitadas que apresentam o espírito do tempo e permitem a visualização de novas referências e, igualmente, de novas representações. A seguir, portanto, realizaremos a descrição e análise dos comerciais, exaltando os elementos fantásticos dentro das situações do dia-a-dia.

O primeiro vídeo a ser analisado é intitulado "Bolota". Postado na página da própria Havaianas no canal do YouTube ${ }^{5}$, conta a história de um cão, chamado Bolota, que sempre rouba as Havainas do dono, interpretado pelo ator Cauã Reymond ${ }^{6}$. Todos os dias, ao acordar, o dono vai calçar o chinelo. Um dos pés do par nunca está onde ele o deixou, como podemos ver na Imagem 1. Ao ir até o pátio para ver o que o cão está fazendo, o dono se depara com o animal de estimação roendo suas Havaianas (Fig. 2).

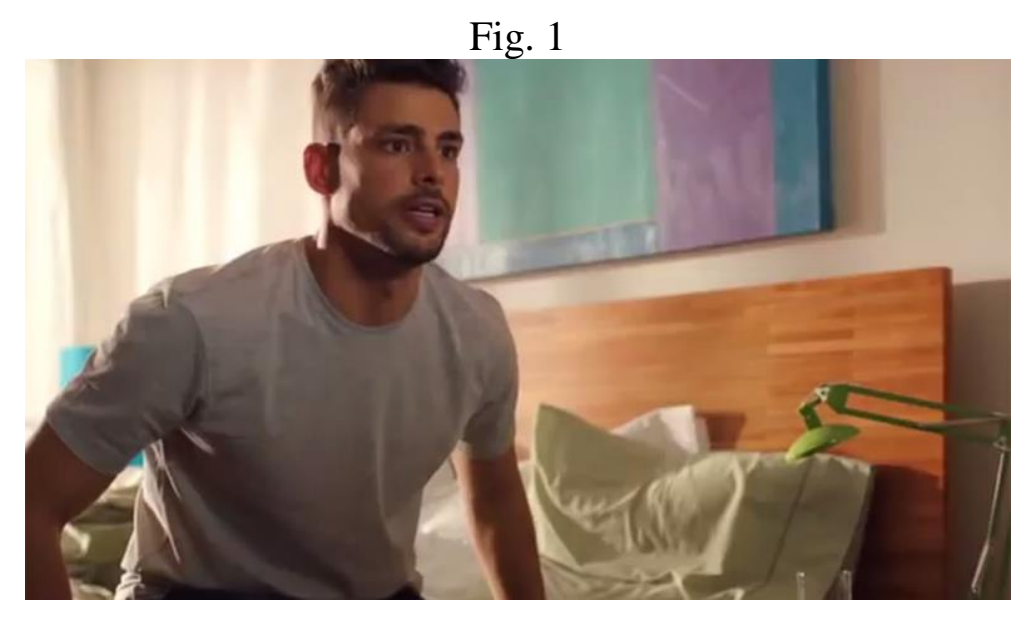

\footnotetext{
${ }^{5}$ Recuperado em 22 fevereiro, 2014, de endereço http://www.youtube.com/watch?v= ZvJafV7ykPQ

${ }^{6}$ Cauã Raymond iniciou sua carreira de modelo, mas tornou-se conhecido como ator. Em 10 anos de carreira, interpretou mais de 20 personagens, e seu currículo contabiliza nove longas-metragens, sete novelas e diversos seriados (Biografia, 2014). Assim, pode ser associado aos ideais de beleza e sucesso, vigentes na contemporaneidade.
} 
O cotidiano fantástico na propaganda de havaianas: O comercial televisivo como tecnologia do imaginário

de Gabriela Kurtz, Juliana Tonin, Karina Pereira Weber e Larissa Azubel

Fig. 2

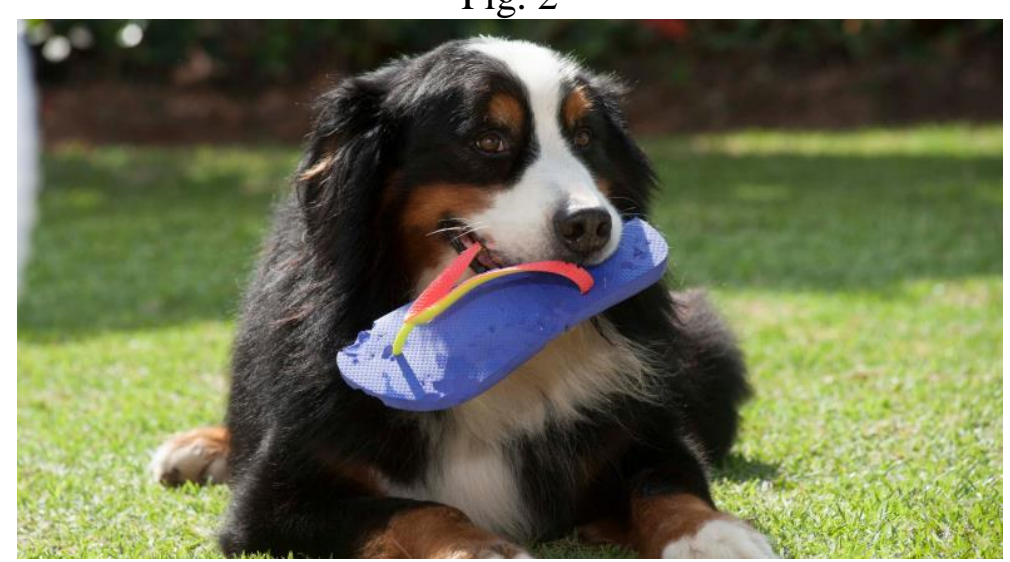

Este fato acontece por mais três dias, que parecem, através do vídeo, ser consecutivos. Então, o dono cansado de ter seus chinelos roídos e inutilizados pelo cão, resolve buscar uma solução. Vai até uma loja de calçados e pede para que lhe vendam uma imitação "bem fajuta" de Havaianas, pensando que assim Bolota não teria mais interesse pelas suas originais (Fig. 3). Ao chegar em casa, o dono vai até o jardim e coloca as imitações de Havaianas na grama, em local próximo de onde o cão fica. Logo, esconde-se no pátio e observa o cachorro, que, ao ver os chinelos e cheirá-los, percebe que não se tratam de Havaianas legítimas e os ignora (Fig. 4).

Fig. 3

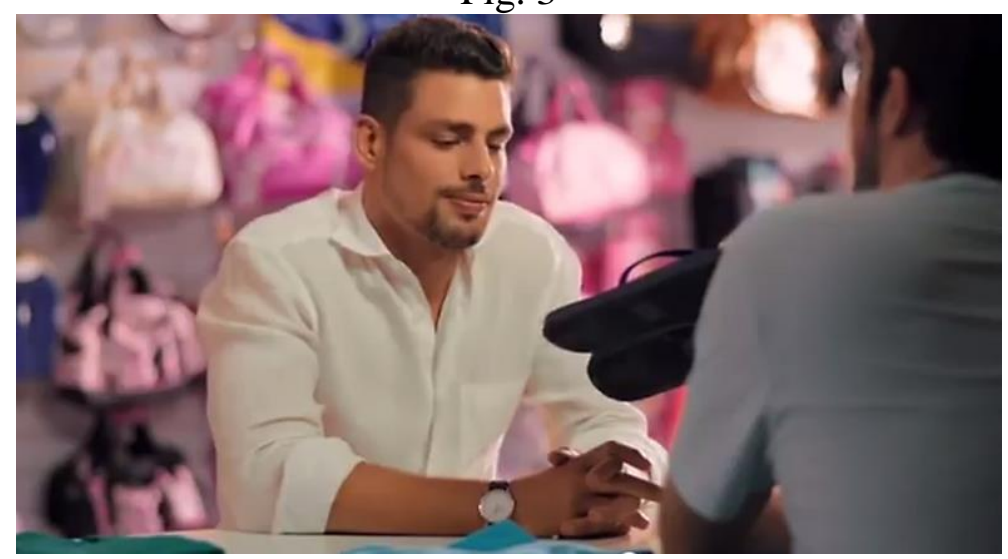


Fig. 4

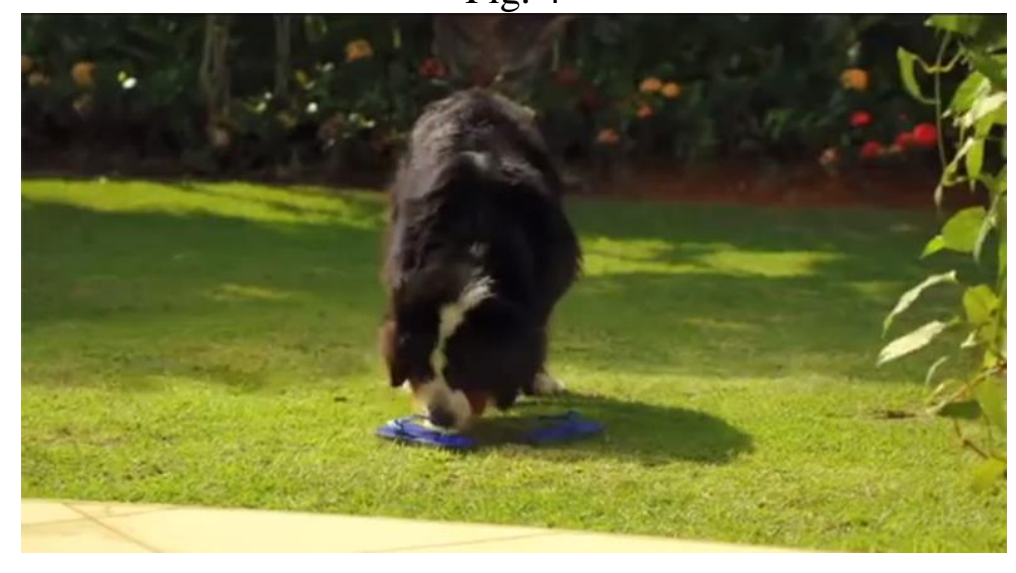

O comercial transmite o interesse e a inteligência do cão em reconhecer a original Havaianas. É uma demonstração do slogan utilizado pela marca: “Todo mundo usa! Recuse imitações!”. A frase imperativa tem uma eficácia potencial tão expressiva, que, no comercial, mesmo o cão travesso obedece.

A propaganda em questão utiliza a narrativa de forma linear e simples, de modo a construir uma expectativa. Com a repetição dos acontecimentos - o cachorro Bolota toda a manhã destrói uma das Havaianas de Cauã -, o personagem principal decide tomar uma providência. Esperamos que o cachorro seja um animal comum, incapaz de perceber a diferença entre um chinelo qualquer e o produto anunciado. O que ocorre é o contrário, a quebra da expectativa: Bolota serve como recurso narrativo para surpreender o espectador e reforçar o posicionamento da marca: ser legítima.

Conseguintemente, a ligação entre o homem e o cachorro, a amizade entre eles pode ser compreendida como uma construção contemporaneamente disseminada, absorvida pelo imaginário atual, faz parte da atmosfera de nosso tempo. Assim, a marca faz uso dessa relação para despertar a empatia e provável simpatia do consumidor pela publicidade de seu produto. Vemos que o imaginário - mesmo que estereotipado, do cachorro sapeca e seu dono descontente com o comportamento, mas orgulhoso da inteligência do amigo canino -, ganha materialidade por meio da tecnologia.

Temos ainda, alguns elementos que facilitam a compreensão por parte de quem assiste: o fato de o personagem principal ser um ator conhecido da TV aberta e estar interpretando ele mesmo, bem como o comportamento comum de cães, de destruir calçados. O primeiro gera a empatia, por conta do ator e de seu poder de persuasão, o segundo gera a identificação, pois é uma situação cotidiana, pela qual muitas pessoas já passaram. O elemento inusitado, então, fica por conta do fato de Bolota reconhecer a 
O cotidiano fantástico na propaganda de havaianas: O comercial televisivo como tecnologia do imaginário

de Gabriela Kurtz, Juliana Tonin, Karina Pereira Weber e Larissa Azubel

qualidade das sandálias e recusar seus instintos animais de destruição ao perceber que foi oferecido a ele uma imitação "fajuta". O cão representa o desejo do exclusivo, de uma marca específica, expondo a sua subjetividade, marcando sua personalidade, como exposto anteriormente com apoio nas ideias de Lipovetsky.

O uso de estereótipos e símbolos de fácil leitura por parte do consumidor fluidificam a narrativa, aumentando no comercial o potencial para a identificação. Além disso, essa tecnologia do imaginário materializa este fantástico, já que a narrativa tem a intenção de reforçar a inteligência, esperteza e bom gosto caninos, para além do humano. É possível fazer a leitura de que, na contemporaneidade, os animais pensam, conhecem, sabem e podem auxiliar seus donos em suas escolhas.

O inusitado, um cão capaz de saber a diferença entre as "legítimas" e as "imitações", aparece no cotidiano do ator, referencial de sucesso. Na lógica da estratégia de venda, poderia estar também no imaginário de cada consumidor que se deixa seduzir, ao desejar se identificar com o discurso de Havaianas. A fantasia presente no cotidiano parece real e desperta ainda mais o desejo do consumidor por ser estatuto de verossimilhança. Em um momento histórico em que, a despeito da nomenclatura, a responsabilidade pela felicidade é individual, podemos ler o consumo de Havaianas como uma oportunidade de adicionar o incrível ao dia-a-dia do brasileiro malandro, que não se deixa enganar, como Bolota.

O segundo anúncio que analisamos é o intitulado "Avó". O comercial também foi disponibilizado no YouTube ${ }^{7}$. Na descrição do vídeo, um breve relato sobre o que é abordado: "O comercial 'Avó' das Havaianas, mostra o charme de Cauã Reymond, que vira o foco de uma conversa entre avó e neta na mesa de um restaurante".

A situação aparece nas imagens 5 e 6 . A avó repreende a neta por ter ido a um restaurante de chinelo. A neta se defende e diz para a avó não ser atrasada, pois não se trata de um chinelo, e, sim, de Havaianas Fit - um modelo de sandália. Sendo assim, pode ser usada em todos os lugares, argumenta a neta.

\footnotetext{
${ }^{7}$ Recuperado em 22 fevereiro, 2014, de endereço http://www.youtube.com/watch?v=KxgTJMZo 8Kg\&list=PL1C47F5038DDDE8CA
} 
O cotidiano fantástico na propaganda de havaianas: O comercial televisivo como tecnologia do imaginário

de Gabriela Kurtz, Juliana Tonin, Karina Pereira Weber e Larissa Azubel

Fig. 5

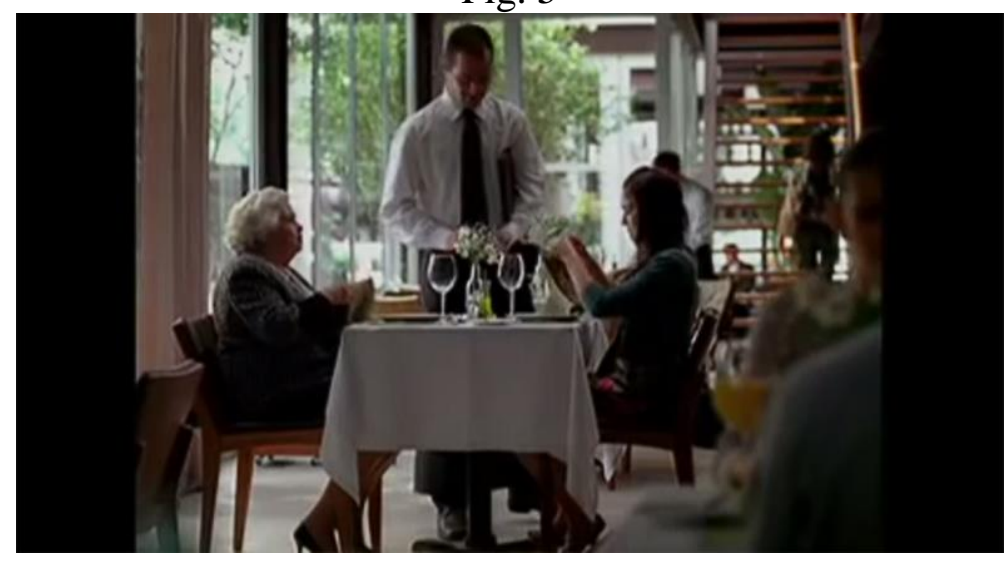

Fig. 6

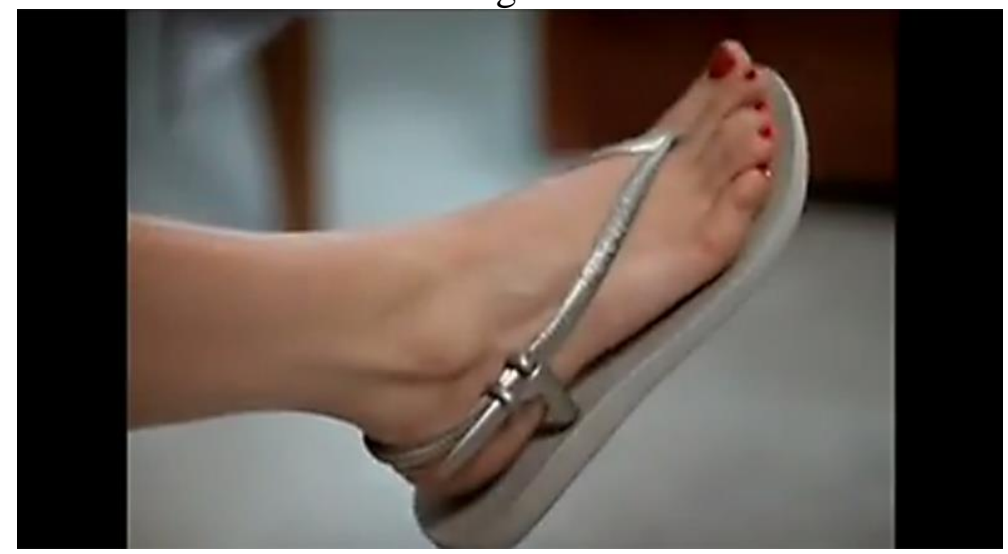

Enquanto as duas conversam, entra no restaurante o ator Cauã Reymond (Fig. 7). A avó aconselha a neta a arrumar um rapaz como ele. A menina diz que deve ser muito chato casar com alguém famoso. A avó logo responde que não está falando em casamento, apenas em sexo. E diz que depois a neta fala que ela é que é a atrasada. A moça fica sem graça, coloca a mão na boca e ri (Fig. 8).

Fig. 7

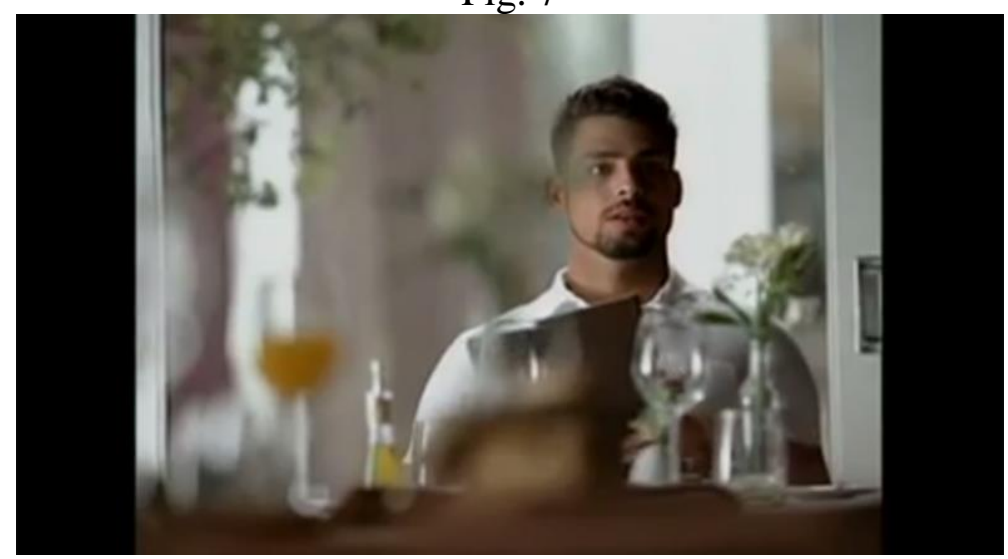


Fig. 8

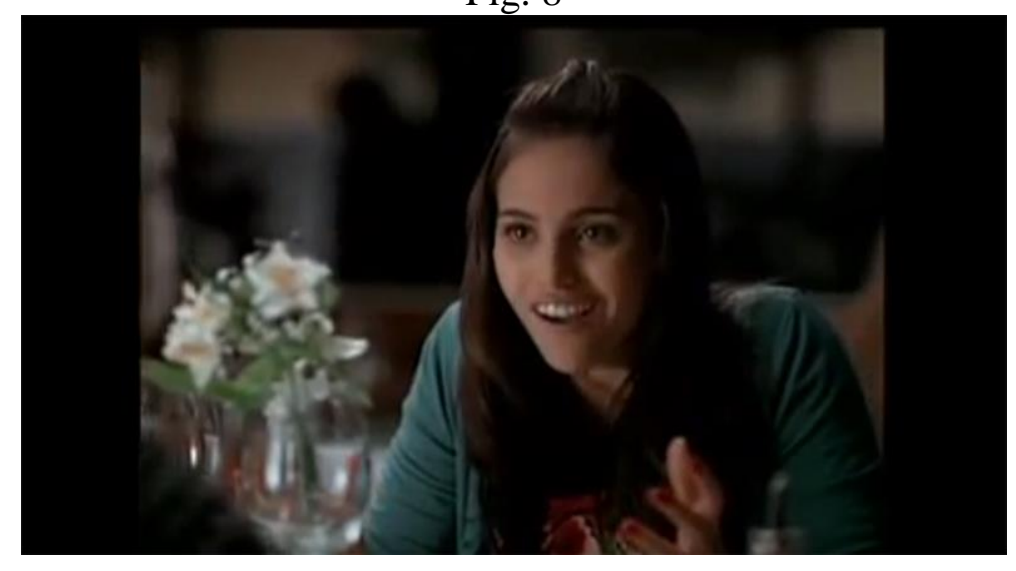

O comercial "Avó" também aplica recursos narrativos bem conhecidos do público. Novamente, a história é linear, mas, desta vez, em uma cena apenas, o que a diferencia do anúncio anterior. A situação é conhecida pelos jovens e jovens adultos: um almoço com a avó. No momento em que o espectador vê a primeira cena, associa a algo cotidiano e completamente plausível. Contudo, ao longo do comercial, a expectativa de a neta possuir pensamentos mais atuais que a avó se inverte, quando a segunda demonstra ter ideias menos conservadoras, quando se trata de relacionamentos, inclusive utilizando a palavra "sexo" em sua fala.

Outro ponto importante, que ajuda a gerar identificação com as pessoas, é a presença de um ator conhecido na TV aberta - novamente o ator Cauã Raymond -, cobiçado principalmente pelo público feminino. O comercial é justamente para mulheres, por conta do produto anunciado. Por isso a importância da situação envolver neta e avó e um ator famoso (com a beleza como principal atrativo).

Esse comercial também versa sobre relação, relacionamento: dessa vez da avó com a neta, um vínculo tradicional, mas "hipermodernizado" pelo conselho da senhora à moça, de arrumar um famoso bonito para fazer sexo. Vemos, assim, que o imaginário das relações interpessoais foi midiaticamente atualizado por Havainas, para dar conta do espírito do tempo presente, com as novas configurações que ele engendra. O desprendimento da avó, que outrora possuíra socialmente a imagem de idosa recatada, plena de conceitos tradicionais sobre família e relacionamentos, apresenta uma nova representação de sua própria figura, incentivando a neta a se desligar dos padrões e de investir em um relacionamento efêmero. 
O cotidiano fantástico na propaganda de havaianas: O comercial televisivo como tecnologia do imaginário

de Gabriela Kurtz, Juliana Tonin, Karina Pereira Weber e Larissa Azubel

Estas duas personas representam a ambiguidade apontada por Lipovetsky que é presente e predominante em nossa sociedade. O paradoxo das condutas tradicionais em contraponto com as novas é manifestado claramente neste comercial e incita para a mudança, uma vez que o novo questiona o velho e vice-versa. Assim, o padrão já foi rompido e acontece a abertura para uma nova formatação das representações.

Sendo um "atraso" a vovó não saber que as sandálias são autorizadas pela moda a circular nos mais diversos ambientes, mais antigo ainda é conservadorismo da neta. Percebemos o comercial como tecnologia de um imaginário de releitura dos papéis sociais, em que destacamos a quebra da expectativa e do preconceito.

\section{CONSIDERAÇÕES FINAIS}

Após a análise dos comerciais, podemos fazer algumas considerações acerca da utilização do inusitado pela publicidade e de seu potencial para manifestar novas referências e representações. O novo ganha materialidade através da propaganda de Havaianas, que se aproxima da vida do consumidor, o qual pode se identificar com algum personagem da cena, inscrita no banal, no comum: o convívio com seu cachorro, uma conversa entre diferentes gerações, em um restaurante.

As situações do dia-a-dia acabam ganhando valores simbólicos não pelos produtos em si, mas pelas narrativas que se somam aos cenários e se sobrepõe a todas as outras histórias que compõem a vida, construindo a complexidade do social. Neste sentido, a publicidade se estende aos momentos da vida, atravessando o cotidiano e construindo, assim, novas representações que irão alimentar o imaginário.

Podemos compreender que Havaianas faz uso inteligente do nível sintomático do imaginário, conforme descrito por Durand (1998): símbolos e alegorias sociais são utilizados para gerar familiaridade com as situações (cotidianas, fantásticas) a fim de otimizar a comunicabilidade e a relação entre consumidor e marca. No imaginário contemporâneo, veiculado pela sandália, fantasia e banalidade se relacionam intimamente. É através de uma relação aparentemente banal entre o homem e seu animal de estimação que podemos perceber quais são os valores vigentes, principalmente, na atualidade, na qual os cães usufruem de uma condição bastante diferenciada, sendo considerados os tradicionais melhores amigos do homem, mas, muitas vezes, mais do que isso, adquirem status de membro da família e recebem toda 
O cotidiano fantástico na propaganda de havaianas: O comercial televisivo como tecnologia do imaginário

de Gabriela Kurtz, Juliana Tonin, Karina Pereira Weber e Larissa Azubel

atenção, respeito e cuidados. O respaldo desses animais é tão grande, na contemporaneidade, que se torna de fácil compreensão, no comercial de Havaianas, o fato de que Bolota é um cão bem tratado e evidenciado como tão ou mais inteligente que seu próprio dono. Manifestação do imaginário atual e consequente nova referência para realimentá-lo.

Assim também acontece na exploração das novas relações sociais, mobilizadas pela mudança nas crenças e valores dessa época. Novas formas de família, novos padrões culturais para idosos, jovens, crianças. O comercial "Avó" registra esse novo padrão e propicia novéis entendimentos sobre esses perfis sociais. Vemos a cultura do tempo presente jorrar pelo imaginário materializado nos comerciais. De forma que podemos compreendê-los, ao modo de Silva (2012), como reservatórios e motores do presente vivido.

\section{REFERÊNCIAS BIBLIOGRÁFICAS}

AVÓ. Recuperdado em 22 fevereiro, 2014, de endereço http://www.youtube.com /watch?v=KxgTJMZo8Kg\&list=PL1C47F5038DDDE8CA

BARBOSA, Livia. Sociedade de consumo. Rio de Janeiro: Zahar, 2004.

BIOGRAFIA. Cauã Reymond. Recuperado em 12 março, 2014, de endereço http://www.cauareymond.com.br/Biografia.aspx

BOLOTA. Recuperado em 22 fevereiro, 2014, de endereço http://www.youtube. $\mathrm{com} /$ watch?v=ZvJafV7ykPQ

DURAND, Gilbert. $O$ imaginário: ensaio acerca das ciências e da filosofia da imagem. Rio de Janeiro: Difel, 1998.

DURAND, Gilbert. As Estruturas Antropológicas do Imaginário (4a ed.). São Paulo: Martins Fontes, 2002.

HISTÓRIA. Site Oficial Havaianas. São Paulo, [201-]. Recuperada em 12 março, 2014, de enderço http://br.havaianas.com/pt-BR/about-havaianas/history/

LIPOVETSKY, Gilles. Os Tempos Hipermodernos. São Paulo: Barcarolla, 2004.

LONGINOTTI-BUITONI, Gian. Luigi. Vendendo sonhos: como tornar qualquer produto irresistível. São Paulo: Negócio Editora, 2000.

LYOTARD, Jean-François. A Condição Pós-Moderna. Rio de Janeiro: José Olympio, 2011. 
O cotidiano fantástico na propaganda de havaianas: O comercial televisivo como tecnologia do imaginário

de Gabriela Kurtz, Juliana Tonin, Karina Pereira Weber e Larissa Azubel

MAFFESOLI, Michel. O conhecimento comum: introdução à Sociologia Compreensiva. Porto Alegre: Sulina, 2010.

MAFFESOLI, Michel. O tempo retorna: formas elementares da pós-modernidade. Rio de janeiro: Forense Universitária, 2012.

MAUSS, Marcel. (1988). Ensaio sobre a Dádiva. Edições 70: Portugal.

PIEDRAS, Elisa Reinhardt. Publicidade, imaginário e consumo: anúncios no cotidiano feminino. E-compós, 11(3), 1-17, 2008. Recuperado em 10 março, 2014, de endereço http://www.compos.org.br/seer/index.php/e-compos/article/viewFile/ $306 / 299$

ROCHA, Everardo. Representações do consumo: estudos sobre a narrativa publicitária. Rio de Janeiro: PUC-Rio; Mauad, 2006.

SILVA, Juremir Machado. As Tecnologias do Imaginário. Porto Alegre: Sulina, 2012.

SHIMP, Terence. A. Propaganda e promoção: aspectos complementares da comunicação integrada de marketing. Tradução de Luciana de Oliveira da Rocha. Porto Alegre: Bookman, 2002.

Artigo submetido: 20/11/2014

Artigo aprovado: 13/04/2015 